\title{
Early period results of arthroscopic anterior cruciate ligament reconstruction with quadrupled hamstring autograft
}

\author{
Dörtlü hamstring otogrefti ile artroskopik ön çapraz băg rekonstrüksiyonunun \\ erken dönem sonuçlart
}

\author{
Selim Şanel, Barıș Kılınç, Ahmet Fırat*, Metin Özdemir, Ali Kağan Gökakın, Ali \\ Öçüder
}

Orthopaedics and Traumatology Clinic (S. Şenel, MD), Orthopaedics and Traumatology Clinic (B. Kılınç, MD), 29 Mayıs Hospital, TR-06450, Gölcük Military Hospital, TR-41040 Kocaeli, Department of Orthopaedics and Traumatology (A. Fırat, MD), Keçiören Training and Research Hospital, TR-06280 Ankara, Department of Physical Therapy and Rehabilitation (M. Ozdemir MD), Üro-Fiz Private Physical Therapy Centre, TR-06500 Ankara, Department of General Surgery (Assist. Prof. A. K. Gökakın, MD), Cumhuriyet University School of Medicine, TR58140 Sivas, Department of Orthopaedics and Traumatology (Assoc. Prof. A. Öçgüder, MD), Atatürk Training and Research Hospital, TR-06800 Ankara

\begin{abstract}
Aim. In recent years there has been an increase in the tendency to use autograft in anterior knee reconstruction. Quadrupled hamstring tendons are known to be the hardest and the most powerful grafts. This study aims to report the first two year results of anterior knee reconstructions performed with proximal femoral transfix fixation by using quadrupled hamstring tendon grafts. Methods. Quadrupled hamstring tendon autografts were used in 89 knees of 89 patients [ 87 male (97.7\%), 2 female (2.3\%)]. The mean age of the patients was 24 years (range 20-34 years). Five patients were professional and 35 patients were amateur sportsmen. Subjective, clinical, functional, Telos stress device, and radiographic evaluations were applied to all patients at the end of the first and second years. International Knee Documentation Committee (IKDC) scoring and Lysholm scoring were used to assess knee function and activity. Results. Subjectively $92 \%$ of the patients expressed their reconstructed knees to be normal with $100 \%$ stability. Eighty-seven percent of the patients returned to their normal daily activities and life at pre-injury level. A and B scores were obtained in 87 of 89 patients $(97.7 \%)$ as average IKDC knee score. The average Lysholm score was 94 . A statistically significant difference was determined in the degree of laxity measured by Telos stress device which had a mean value of $13.7 \mathrm{~mm}$ preoperatively and $2.8 \mathrm{~mm}$ postoperatively. Conclusion. Successful and excellent subjective, objective, functional and radiological results were obtained in the early follow-up period with the endoscopic anterior cruciate ligament reconstruction technique performed by using femoral transfix fixation with quadrupled semitendinosus-gracilis autograft.
\end{abstract}

Keywords: Anterior cruciate ligament, hamstring autograft, arthroscopy

\section{Özet}

Amaç. Son yıllarda daha çok ön çapraz bağ rekonstrüksiyonunda otogreft kullanma eğiliminde artış vardır. Bilinen en sert ve en güçlü greft dörtlü hamstring tendonlarıdır. Amacımız dörtlü hamstring tendon greftini kullanarak proksimal femoral transfix fiksasyonu ile yapılan ön çapraz bağ rekonstrüksiyonunun ilk 2 yıllık sonuçlarını yayınlamaktır. Yöntemler. Seksen dokuz hastanın [87 erkek $(\% 97,7), 2$ kadın $(\% 2,3)] 89$ dizinde dörtlü hamstring tendon otogrefti kullanılmıştır. Hastaların yaş ortalaması 24 (20-34 yaş arası) idi. 5 hasta profesyonel, 35 hasta amatör sporcuydu. Subjektif, klinik, fonksiyonel, Telos stres cihazı ve radyografik değerlendirmeler, 1. ve 2. Yılın sonunda her hasta için uygulanmıştır. Diz fonksiyon ve aktivitesini değerlendirmek için International Knee Documentation Committee (IKDC) ve Lysholm diz skoru kullanıldı. Bulgular. Subjektif olarak hastaların \%92'si rekonstrükte edilen dizlerini \%100 stabilite ile normal kabul etmişlerdir. \%87'si zedelenme öncesi aktivite düzeyine dönmüşlerdir. Ortalama IKDC diz skoru olarak 89 hastanın 87'sinde $(\% 97,7)$ A ve B skorları elde edildi. 
Lysholm ortalama skoru 94 olarak bulundu. Telos stres cihazı ile ameliyat öncesi ortalama $13,7 \mathrm{~mm}$ ve ameliyat sonrası ortalama $2,8 \mathrm{~mm}$ ölçülen laksite değerleri arasında anlamlı fark bulundu. Sonuç. Femoral transfix fiksasyonu ile dört katlı semitendinosus-grasilis otogrefti kullanarak yapılan endoskopik ön çapraz bağ rekonstrüksiyonu tekniğinde erken dönemde başarılı ve mükemmel subjektif, objektif, fonksiyonel ve radyolojik sonuçlar elde ettik.

Anahtar sözcükler: Ön çapraz bağ, hamstring otograft, artroskopi

Geliş tarihi/Received: November 19, 2011; Kabul tarihi/Accepted: August 02, 2012

\section{*Corresponding author:}

Dr. Ahmet Firat, Ortopedi ve Travmatoloji Anabilim Dalı, Keçiören Training and Research Hospital, TR-06280Ankara. E-mail: ahmetfirat24@yahoo.com

\section{Introduction}

In the choice of grafts, autografts are secondary for most orthopedists. Due to the additional problems created by the use of patellar tendons, a minority of orthopedists use hamstring tendons as a graft choice. Quadrupled hamstring tendons are known to be the strongest and hardest graft. The strength of quadrupled hamstring tendons is between $4108 \mathrm{~N}$ and $4213 \mathrm{~N}$. This level equates to approximately double the strength of a normal anterior cruciate ligament (ACL) and $138 \%$ of the strength of a $10 \mathrm{~mm}$ patellar tendon graft. [1, 2] The stiffness of quadrupled hamstring tendons varies between $807 \mathrm{~N} / \mathrm{mm}$ and $954 \mathrm{~N} / \mathrm{mm}$, which is on average 3 times that of a normal ACL and twice that of a patellar tendon $[3,4]$. The most attractive feature of the use of hamstring tendons is that there is very little or no harm to the patient [5]. This study presents the 2 year (early period) results of suitable cases of ACL reconstruction using quadrupled semitendinosus and gracilis autograft for fixation with proximal femoral TransFix (Arthrex, Naples, FL, ABD).

\section{Material and methods}

This retrospective study was approved by the prevailing Institutional Review Boards. Informed consent was obtained from the study population. An evaluation was made of 89 patients [87 male (97.7\%), 2 female $(2.3 \%)$ ] who had undergone primary arthroscopic ACL reconstruction with quadrupled semitendinosus and gracilis autograft applied by the proximal femoral transfix fixation method between November 2006 and November 2008 with a minimum follow-up of 1 year (mean 15 months; range 12-24 months). The mean age of the patients was 24 years old (range 20-34 years). Five patients were professional sportsmen and 35 were amateurs. The patient history was taken and a physical examination made. Lachman and pivot shift tests were applied and the diagnosis was confirmed by magnetic resonance imaging (MRI). Sound from the knee during exercise followed by rapid swelling and pain was reported by $94 \%$ of the patients. All patients underwent surgery on one knee; $59(66.2 \%)$ on the right side and $30(33.8 \%)$ on the left. Only 1 patient required revision surgery due to loosening. Approximately 1 month preoperatively each patient had been given a quadriceps exercise programme. All the operations were performed under spinal or epidural anaesthesia. The autograft being harvested was quadrupled and fixed arthroscopically proximally to the femur with a cross screw (Transfix) and distally to the tibia with absorbable soft tissue screw or a U-screw (Figure 1 and 2). During the operation, 83 patients were determined as having the additional pathology of torn meniscus and in 16 patients chondropathy. The Grade II and Grade III chondropathy patients underwent debridement and drilling. The patients with torn meniscus underwent partial menisectomy by radiofrequency and mechanical instruments. Meniscus repair was not applied to any patient (Table 1). 


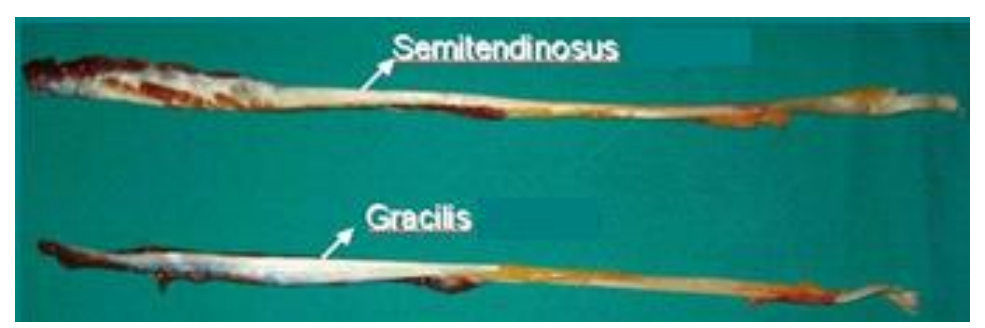

Figure 1. Harvested autografts.

Table 1. Operative findings.

\begin{tabular}{|c|c|c|c|c|c|}
\hline \multirow[t]{2}{*}{$\mathrm{N}=89$} & \multicolumn{3}{|c|}{ Chondromalasia } & \multicolumn{2}{|c|}{ Meniscus tear } \\
\hline & Lateral & Medial & Patellofemoral & Medial & Lateral \\
\hline & Compartment & Compartment & Area & Meniscus & Meniscus \\
\hline & None: 85 & None: 82 & None: 84 & Tear: 52 & Tear: 31 \\
\hline & Grade I: 2 & Grade I: 4 & Grade I: 3 & Partial & Partial \\
\hline & & & & Menisectomy: 52 & Menisectomy: 31 \\
\hline & Grade II: 2 & Grade II: 1 & Grade II: 2 & Repair: none & Repair: none \\
\hline & Grade III: 0 & Grade III: 2 & Grade III: 0 & & \\
\hline & Grade IV: 0 & Grade IV: 0 & Grade IV: 0 & & \\
\hline
\end{tabular}

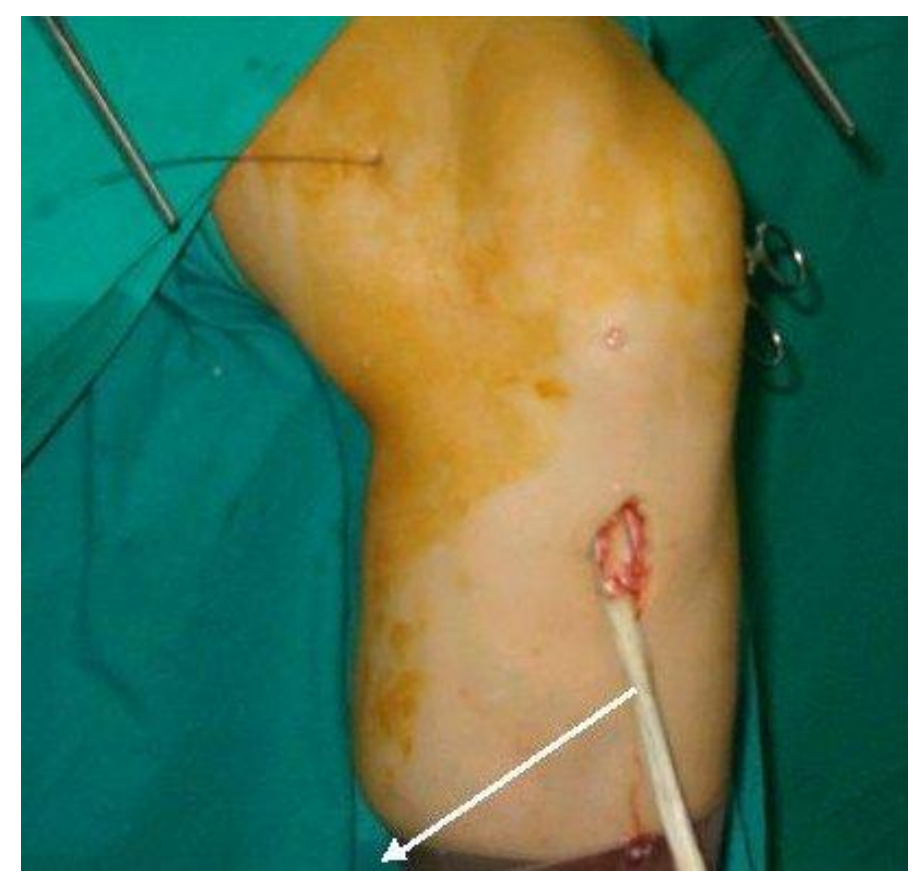

Figure 2. Placement of quadrupled hamstring autograft.

At the end of the operation a hemovac drain was applied to each patient. As standard procedure, all patients were administered 1 dose of first generation cephalosporin (cephazoline sodium) preoperatively and for 5 days postoperatively. One patient developed a surface infection, which was treated with dressings and antibiotics. All patients started isometric quadriceps exercises on the same day after the operation and the next day after removing the hemovac and changing the dressing, isokinetic exercises were started. An adjustable hinged knee brace was applied to all patients as additional support. For the first 3 weeks, the knee brace was adjusted to allow movement between $0^{\circ}$ and $90^{\circ}$ and then the angle was left free for a total of one and a half months' use. Exercises were continued after the brace was removed. Non-competitive sports were allowed at the end 
of six months and after nine months the patients were unrestricted. The stitches were removed on postoperative day 15. All patients were mobilised after the first dressing was changed and the hemovac drain was removed. At the first and the second year, all patients were evaluated subjectively, clinically, functionally, radiologically and by Telos stress device measurements. Statistical analysis was performed using the SPSS version 15.0 (SPSS, Inc., Chicago, IL). Consistency of the data with anormal distribution was assessed using the Kolmogrov Simirnov test. Statistical significance level was set at $\mathrm{p}<0.05$ for all tests. Preoperatively and postoperatively outcomes of Telos measurements, The International Knee Documentation Committee (IKDC) scores and Lysholm scores were compared by using Independent samples t-test.

\section{Results}

Subjectively, the reconstructed knee was accepted as normal with $100 \%$ stability by $92 \%$ of the patients and $87 \%$ returned to their pre-injury level of activity. A questionnaire using The IKDC scores and Lysholm scores were used to evaluate activities to assess function. The mean IKDC knee evaluation system scores were $72 \pm 4.4$ preoperatively and $88.6 \pm 6.8$ postoperatively $(\mathrm{p}<0.05$ ). According to 2000 IKDC knee form, the patients were classified from $\mathrm{A}$ to $\mathrm{D}$ ( $\mathrm{A}=$ Normal, $\mathrm{B}=$ Nearly normal, $\mathrm{C}=\mathrm{Abnormal}, \mathrm{D}=$ Severely abnormal). The mean IKDC was A or B for 87 (97.7\%) patients. (Table II).

Table 2. IKDC evaluation score results.

\begin{tabular}{ll}
\hline Grade & No. of patients \\
\hline A (Normal) & 63 \\
B (Nearly normal) & 24 \\
C (Abnormal) & 1 \\
D (Bad) & 1 \\
\hline
\end{tabular}

The mean Lysholm knee score was $76.7 \pm 6.3$ preoperatively, $94 \pm 5.2$ postoperatively $(\mathrm{p}<0.05)$ (evaluation out of 100 points). Measurements were taken with the Telos stress device applying a force of $15 \mathrm{~kg}$ and lateral radiographs were taken of both knees (Figure $3)$. The distance was measured between the posterior femoral condyle and the tibial plateau posterior edge. The pathological knees were compared to the healthy knees. Preoperative mean laxity values were significantly higher than of the postoperative values (13.7mm versus $2.8 \mathrm{~mm}, \mathrm{p}<0.001$ ) (Figure 4 and 5).

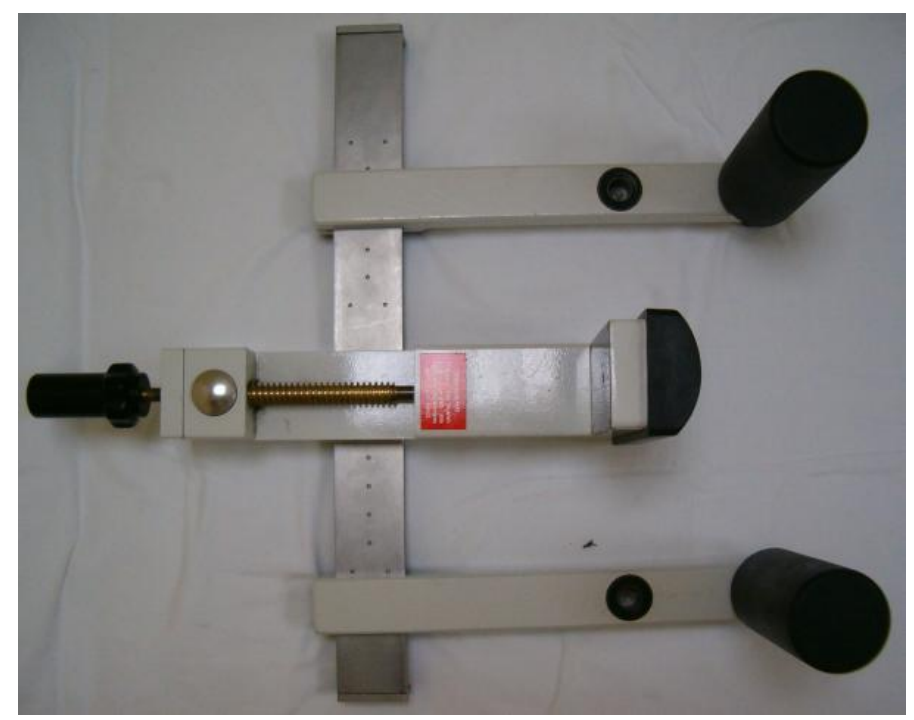

Figure 3. Telos stress device. 

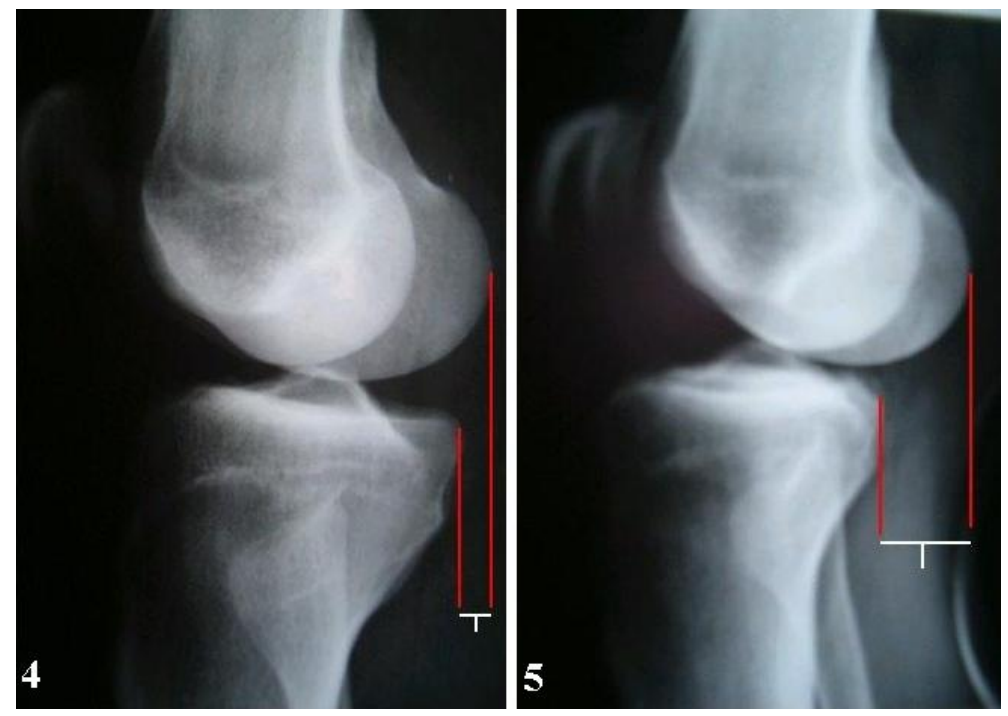

Figure 4. Normal knee. 5. Knee with ACL tear.

One patient who was Grade $\mathrm{C}$ according to the IKDC scoring system underwent a 'second look' arthroscopy. Having completed the ligamentisation and determined that there was no excessive looseness of the ligament, the patient was started on a rehabilitation programme, after which, as the patient's complaints had receded, ligament revision was not deemed necessary. The patient who was Grade D according to the IKDC scoring system underwent revision 11 months after the first operation. The high degree of graft loosening in this patient was related to a repeated trauma. During the revision, a widening of both tunnels was determined. Nevertheless, the ligamentisation was seen to be completed at the femoral and tibial tunnel openings. At the 6 month evaluation after revision using allograft, the IKDC score was accepted as Grade B and the Lysholm score was 89. Surface infection developed in one patient which was treated with dressings and systemic antibiotics. No complications such as deep vein thrombosis or reflex sympathetic dystrophy were encountered in any patient. There was a slight loss of feeling in the incision area of the graft harvest in 8 patients. No patient required the removal of the tibial fixation material.

\section{Discussion}

As there have been both reduced deterioration of grafts and developments in sterilisation and storage conditions in recent years, there are publications supporting the use of allografts in ACL reconstruction [6,7]. On the other hand, when 2 of the 3 medial muscles of the knee are reached from the stabiliser, loss (functional, subjective, objective and radiographic values) is minimal with reconstruction using semitendinosus and gracilis graft $[8,9]$. Several sources do not recommend the use of quadrupled hamstring graft on patients who are overweight (over $90 \mathrm{~kg}$ ), those who run short distances, those with a pivot-shift test of +4 , those with medial ligament laxity or those with general joint looseness [10, 11]. In our clinic, patients with those findings were not treated with quadrupled hamstring graft. The fixation materials should be suitable for an intensive and rapid rehabilitation programme, particularly in the early postoperative period, should be as resistant as possible and biocompatible, should not prevent recovery and should allow for normal joint functions [12, 13]. In a biomechanical study by Johnson et al. [14], it was found that when the fixation materials were exposed to loads between $400-800 \mathrm{~N}$, in the postoperative intensive rehabilitation programme and in daily activities, the mean load was 500N. Indelicato et al. [15] determined increased chondrial and meniscal damage in chronic ACL tears compared to acute ACL tears. Similarly, in our study, a higher rate of chondrial and meniscal damage was found in chronic cases.In a study by Sgaglione et al. [16], the reconstruction results of the chronic group were reported as worse when 
compared to the acute group as more meniscal damage was seen in the chronic group. Possibly due to the short follow-up time, no significant difference was seen between the two groups in our study in the early period. In a study evaluating the load resistance, stiffness and stripping force of femoral fixation materials, Vander Reis et al. [17] demonstrated the strongest materials to be Endobutton CL and CrossPin system (Transfix). Evaluating tibial fixation of grafts, Klein et al. [18] reported that screw-staple, screw-stamp and fastlock fixation systems were more resistant to greater loads in comparison to other systems. In a study by Goradia et al. [19], the fixation material was removed in $27 \%$ of the patients because of pain and in the $50 \%$ of the patients, slight problems were seen in the incision site related to the screw/stamp fixation material in the tibia.Absorbable soft tissue screws and staple were used for graft tibial fixation in our patients. There was no requirement to remove the tibial fixation material in any patient and complaints of slight loss of feeling in the incision area were only encountered in 8 patients. Therefore, we believe that the ideal method for tibial fixation is the combination of absorbable soft tissue screws and U-screws. Ma et al. [20] reported that better bone tendon union was achieved by cross-screw (Transfix) methods where the hamstring tendons are femorally fixed from the far end of the tunnel in comparison to fixation with screws inside the tunnel. At least the whole tendon is in contact with the bone and the recovery surface is increased. In cases where fixation is made with screws, the screw remains between the bone and the tendon. One point to which attention must be paid when using Transfix is that the diameter of the tendon and the diameter of the tunnel must be the same. Thus, less sinovial fluid enters the tunnel and the possibility of the tunnel widening is reduced [20].

In conclusion, successful and excellent results were obtained supported by the evaluation scores and tests in our patients from ACL reconstruction performed using femoral transfix fixation with quadrupled hamstring tendon autograft.

\section{References}

1. Butler DL, Grood ES, Noyes FR, Sodd AN. On the interpretation of our anterior cruciate ligament data. Clin Orthop Relat Res 1985; 196: 26-34.

2. Barber FA, Small N, Click J. Anterior cruciate ligament reconstruction by semitendinosus and gracilis tendon autograft. Am J Knee Surg 1991; 4: 84-9.

3. Karahan M: Ön çapraz bağ yaralanmalarında dörtlü hamstring tendonları (semitendinosus/gracilis) ile rekonstrüksiyon. In: Tandoğan NR, editör. Ön çapraz bağ cerrahisi. Ankara: Spor yaralanmaları, Artroskopi ve Diz Cerrahisi Derneği; 2002; ss: 91-8.

4. Pinczewski LA, Clingeleffer AJ, Otto DD, Bonar SF, Corry IS. Integration of hamstring tendon graft with bone in reconstruction of the anterior cruciate ligament. Arthroscopy 1997; 13: 641-3.

5. Noyes FR, Barber-Westin SD. A comparison of results in acute and chronic anterior cruciate ligament ruptures of arthroscopically assisted autogenous patellar tendon reconstruction. Am J Sports Med 1997; 25: 460-71.

6. Seo SS, Kim CW, Nam TS, Choi SY. ACL Reconstruction with Autologous Hamstring Tendon: Comparison of Short Term Clinical Results between Rigid-fix and PINN-ACL Cross Pin. Knee Surg Relat Res 2011; 23: 208-12.

7. Paxton ES, Stock MV, Brophy RH. Meniscal repair versus partial meniscectomy: a systematic review comparing reoperation rates and clinical outcomes.

Arthroscopy 2011; 27: 1275-88.

8. Sekiya I, Muneta T, Ogiuchi T, Yagishita K, Yamamoto H. Significance of the single-legged hop test to the anterior cruciate ligament-reconstructed knee in relation to muscle strength and anterior laxity. Am J Sports Med 1998; 26: 384-8.

9. Warnock M, Elkousy H. Recent issues in anterior cruciate ligament surgery. Curr Opin Orthop 2004; 15: 86-91.

10. Brown CH, Wilson DR, Heckor AT, Ferragamo, M. Comparison of hamstring and 
pateller tendon fixation: cyclic load. Book of Abstract, 25th Annual Meeting American Orthopaedic Society of Sports Medicine, Traverse City, Michigan 1999; pp: 413-4.

11. Barrack RL, Bruckner JD, Kneisl J, Inman WS, Alexander AH. The outcome of non-operatively treated complete tears of the anterior cruciate ligament in active young adults. Clin Orthop Relat Res 1990; 259: 192-9.

12. McGuire DA, Barber FA, Milchgrub S, Wolchbok JC. A postmortem examination of poly-L-lactic acid interference screws 4 months after implantation during anterior cruciate ligament reconstruction. Arthroscopy, 2001; 17: 988-92.

13. Atik OS. Is reconstruction of the anterior cruciate ligament a prerequisite for restoring muscle function? Eklem Hastalık Cerrahisi 2009; 20: 125-6.

14. Johnson D, et al. All soft tissue graft fixation techniques. Which should I use? Screws, cross pins, buttons? AANA, Specialty Day, San Francisco 2001, Abstract Books; pp: 99-102.

15. Indelicato PA, Bittar ES. A perspective of lesions associated with ACL insufficiency of the knee. A review of 100 cases. Clin Orthop Relat Res 1985; 198: 77-80.

16. Sgaglione NA, Del Pizzo W, Fox JM, Friedman MJ. Arthroscopically assisted anterior cruciate ligament reconstruction with the pes anserine tendons. Comparison of results in acute and chronic ligament deficiency. Am J Sports Med 1993; 21: 249-56.

17. Vander Reis WL, Deffner KT, Rosenberg TD. Comparison of hamstring fixation devices under cyclic and other loading. AOSSM, Specialty Day. Orlando FL 2000, Abstract Books; pp: 88-9.

18. Klein JP, Linter DM, Downs D, Vavrenka K. The incidence and significance of femoral tunnel widening after quadrupled hamstring anterior cruciate ligament reconstruction using femoral cross pin fixation. Arthroscopy 2003; 19: 470-6.

19. Goradia VK, Grana WA. A comparison of outcomes at 2 to 6 years after acute and chronic anterior cruciate ligament reconstructions using hamstring tendon grafts. Arthroscopy 2001; 17: 383-92.

20. Ma CB, Francis K, Towers J, Irrgang J, Fu FH, Harner CH. Hamstring anterior cruciate ligament reconstruction: a comparison of bioabsorbable interference screw and endobutton-post fixation. Arthroscopy 2004; 20: 122-8. 